\title{
PENINGKATAN PRODUKTIVITAS PETANI DALAM PENGOLAHAN JERUK NIPIS MENJADI PRODUK MINUMAN KESEHATAN DAN SABUN
}

\author{
Kartini, Alfian Hendra Krisnawan, \& Nikmatul Ikhrom Eka Jayani \\ Departemen Biologi Farmasi, Fakultas Farmasi, Universitas Surabaya \\ kartini@staff.ubaya.ac.id
}

\begin{abstract}
Abstrak
Kurangnya pengetahuan dan ketrampilan petani jeruk nipis dalam pengolahan produk berbahan jeruk nipis, menjadi permasalahan ketika panen melimpah. Kegiatan pengabdian kepada masyarakat ini bertujuan untuk membantu para petani jeruk nipis dalam meningkatkan kapasitas dan kualitas serta nilai jual jeruk nipis melalui pembuatan modul, pelatihan pembuatan minuman kesehatan dan sabun cuci tangan berbahan dasar jeruk nipis serta pendampingan selama program pengabdian. Dari kegiatan yang dilakukan dapat disimpulkan bahwa penguasaan pengetahuan dan ketrampilan dalam mengolah jeruk nipis dapat meningkatkan produktivitas petani.

Kata Kunci: produktivitas, jeruk nipis, pengabdian, minuman kesehatan, sabun.
\end{abstract}

\section{PENDAHULUAN}

Buah jeruk nipis berdiameter 3,5 sampai $5 \mathrm{~cm}$, memiliki warna hijau ketika masih muda dan menjadi kuning setelah tua. Biji berbentuk bulat telur, pipih, putih, putih kehijauan (Syamsulhidayat dan Hutapea, 1991). Secara taksonomi, tanaman jeruk nipis (Citrus aurantifolia) termasuk dalam famili Rutaceae (Apraj et al., 2011). Tanaman jeruk nipis merupakan tanaman yang banyak dibudidayakan di seluruh dunia. Penggunaan jeruk nipis untuk dikonsumsi dari jeruk nipis segar maupun produk olahannya. Perasan air jeruk nipis digunakan sebagai perasa makanan, dikonsumsi langsung sebagai jus maupun dijadikan selai dan olahan makanan lainnya. Produk lain dari jeruk nipis adalah minyak esenssial yang didapatkan dari destilasi pada kulit buah. Minyak jeruk nipis dapat dimanfaatkan sebagai perasa, parfum, pembuatan sabun, industri kosmetik dan farmasi (Ferguson, 1990; Nwachukwu et al., 2007).
Di Nigeria perasan air Jeruk nipis yang dicampur dengan madu dimanfaatkan sebagai obat batuk. Di Malaya dimanfaatkan untuk tonikum, meningkatkan libido dan antidot racun, meningkatkan stamina, peremajaan kulit, athralgia, diabetes dan aterosklerosis. Perasan air jeruk nipis yang diencerkan juga dapat dimanfaatkan sebagi obat kumur untuk mengobati radang/sakit tenggorokan (Aibinu, 2007; Khare, 2007). Kandungan senyawa kimia yang terkait efek farmakologis pada jeruk nipis adalah flavonoid, saponin, asam sitrat dan minyak atsiri. Penelitian secara invitro menunjukkan air perasan jeruk nipis pada konsentrasi efektif $8 \%$ memiliki aktivitas antibiofilm pada bakteri Staphylococcus aureus (Firda, 2015). Penelitian tersebut menunjukkan potensi jeruk nipis sebagai antibakteri. Penambahan minyak atsiri jeruk nipis dalam sediaan sabun mandi cair sebagai agen antibakteri dapat meningkatkan efektivitas sabun dalam fungsinya sebagai pembersih kulit (Apriyani, 2013). 
Selain memiliki sifat sebagai atibakteri, air perasan jeruk nipis juga terbukti mampu menurunkan kolesterol total darah. Pada penelitian yang dilakukan oleh Elon (2015), menunjukkan bahwa terapi jus jeruk nipis yang disertai dengan olah raga yang rutin mampu menurunkan kadar kolesterol darah. Hasil penelitian juga menunjukkan air perasan jeruk nipis dan kulit jeruk nipis mempunyai efek sebagai antioksidan yang kuat karena kandungan flavonoidnya (Bostham, 2011). Penelitian lain pada kulit buah dan daunnya juga menunjukkan efek antioksidan yang tinggi dan berpotensi dikembangkan menjadi pangan fungsional (Loizzo et al., 2012). Pangan fungsional merupakan makanan atau minuman yang mengandung bahanbahan yang dapat meningkatkan status kesehatan dan mencegah timbulnya penyakit tertentu. Salah satu komponen pangan fungsional yang mempunyai fungsi fisiologis bagi tubuh adalah antioksidan. Asupan antioksidan setiap hari dapat mengurangi peluang munculnya gejala penyakit degeneratif dan mampu memperlambat penuaan (Papas, 1998).

Desa Tinggar merupakan salah satu desa yang berada di Kecamatan Bandarkedungmulyo Kabupaten Jombang yang pada tahun 1980-an dikenal sebagai sentra jeruk nipis. Sampai sekarang pun masih banyak penduduk desa yang memiliki tanaman jeruk nipis di pekarangan rumahnya. Petani jeruk nipis di Desa Tinggar bisa memanen 20-30 hari sekali dengan hasil 4-10 20 $\mathrm{kg} /$ pohon. Jadi, untuk petani yang memiliki 100 batang pohon akan menghasilkan 400$1000 \mathrm{~kg}$ buah tiap kali panen. Ini merupakan nilai yang cukup tinggi. Petani jeruk nipis biasanya hanya menjual hasil panen pada tengkulak secara langsung. Oleh karena itu, ketika tanaman sedang berbuah banyak dan harga jual rendah, petani sering membiarkan buah berjatuhan dan tidak dipanen. Melalui program IbM Petani Jeruk Nipis Desa Tinggar Kecamatan Bandarkedungmulyo Kabupaten Jombang, telah dilakukan pendampingan kepada petani mitra dalam pengolahan jeruk nipis menjadi produk minuman kesehatan dan sabun. Kegiatan ini diharapkan dapat meningkatkan produktivitas petani dalam membuat produk olahan jeruk nipis yang bernilai tinggi.

\section{METODE PELAKSANAAN}

Penerapan dan transfer teknologi peningkatan produktivitas dan pembuatan produk olahan jeruk nipis dilakukan melalui penyuluhan, pelatihan, dan aplikasi langsung. Kegiatan dilaksanakan di Desa Tinggar Kecamatan Bandarkedungmulyo Kabupaten Jombang, Provinsi Jawa Timur selama enam bulan (mulai bulan Mei sampai bulan Oktober 2017). Program pendampingan juga dilakukan untuk evaluasi keberhasilan program. Penanggung jawab kegiatan adalah tiga orang dosen Universitas Surabaya, dibantu seorang staf LPPM Universitas Surabaya serta empat mahasiswa Fakultas Farmasi Universitas Surabaya. Target kegiatan adalah para istri petani jeruk nipis ke- 
lompok mitra dan ibu-ibu kader PKK di Desa Tinggar Kecamatan Bandarkedungmulyo Kabupaten Jombang, Provinsi Jawa Timur dengan total peserta mencapai 35 orang.

\section{Pembuatan Modul Pelatihan Cara}

\section{Mengolah Jeruk Nipis}

Modul yang dibuat berisi informasi beberapa produk olahan baik pangan maupun non pangan yang bisa dibuat dengan memanfaatkan jeruk nipis. Modul ini disusun oleh tim IbM Petani Jeruk Nipis Desa Tinggar Kecamatan Bandarkedungmulyo Kabupaten Jombang.

\section{Pelatihan Pembuatan Minuman}

\section{Kesehatan Berbahan Dasar Jeruk Nipis}

Pelatihan diberikan dengan pemberian materi terlebih dahulu dilanjutkan dengan praktek pembuatan produk minuman fungsional segar, minuman instan serbuk dengan bahan jeruk nipis dan pembuatan sabun dengan perasan air jeruk nipis.

\section{Penyerahan Alat Produksi}

Pada saat pelatihan, diserahkan alatalat pendukung proses produksi minuman kesehatan dan sabun dari jeruk nipis. Alatalat yang disediakan diharapkan dapat langsung dimanfaatkan untuk kegiatan poduksi. Alat-alat yang diserahkan antara lain alat peras jeruk nipis, alat press tutup kemasan minuman instan (cup sealer), blender, panci, kompor gas, oven, dan mixer.

\section{Monitoring dan Pendampingan Paska Pelatihan Pembuatan Produk Olahan \\ Jeruk Nipis}

Satu bulan setelah kegiatan pelatihan, tim pelaksana melakukan diskusi untuk memantau dan menindaklanjuti hasil transfer pengetahuan dan teknologi kepada kelompok mitra.

\section{HASIL DAN PEMBAHASAN}

\section{Pembuatan Modul Pelatihan Cara}

\section{Mengolah Jeruk Nipis}

Pada kegiatan ini telah disiapkan modul "Cara mengolah jeruk nipis" berisi panduan ringkas beberapa alternatif pengolahan jeruk nipis menjadi produk makanan-minuman kesehatan (Gambar 1). Panduan disertai dengan gambar-gambar yang dapat memudahkan pembaca untuk memahami prosedur yang dimaksud.

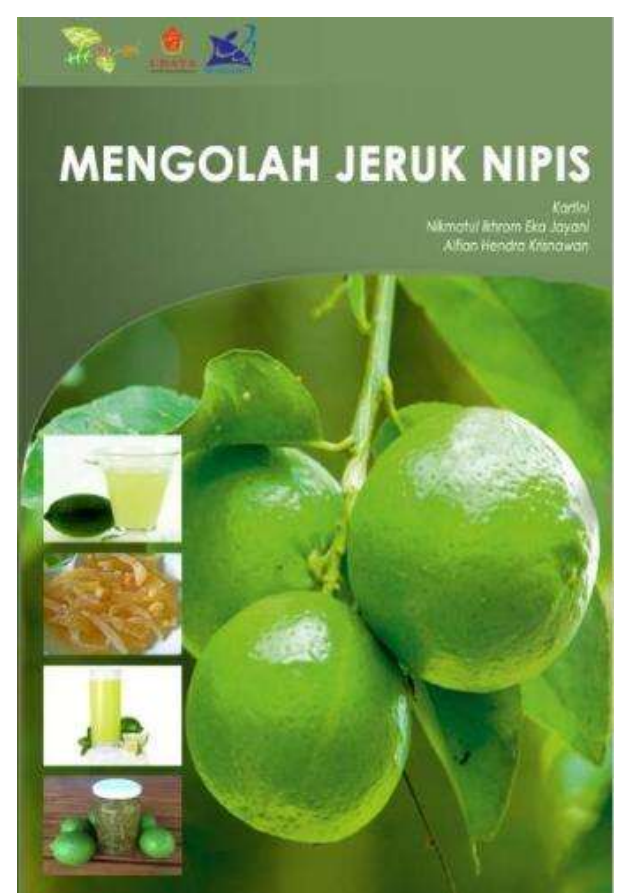

Gambar 1 Halaman sampul modul mengolah jeruk nipis. 
Metode pengolahan jeruk nipis yang disajikan dalam buku ini dapat diterapkan dalam skala rumah tangga untuk keperluan sendiri maupun yang ingin memulai bisnis makanan-minuman olahan. Modul disertai dengan gambar dan bagan yang menarik agar mudah diikuti.

\section{Pelatihan Pembuatan Minuman}

\section{Kesehatan Berbahan Dasar Jeruk Nipis}

Kegiatan pelatihan pembuatan minuman kesehatan dan sabun berbahan dasar jeruk nipis telah dilakukan pada hari Sabtu, 12 Agustus 2017. Sebelum pelatihan dimulai terlebih dahulu diberikan sosialisi terkait dengan kegiatan yang akan dilakukan melalui pendampingan IbM. Kegiatan melibatkan 35 orang ibu-ibu istri petani jeruk nipis mitra dan kader PKK (Gambar 2). Tim pelaksana pengabdian yang terdiri dari dosen dan mahasiswa menyampaikan materi pelatihan dengan media slide ppt yang dilanjutkan dengan praktek langsung. Diskusi dua arah juga dilakukan selama kegiatan berlangsung.

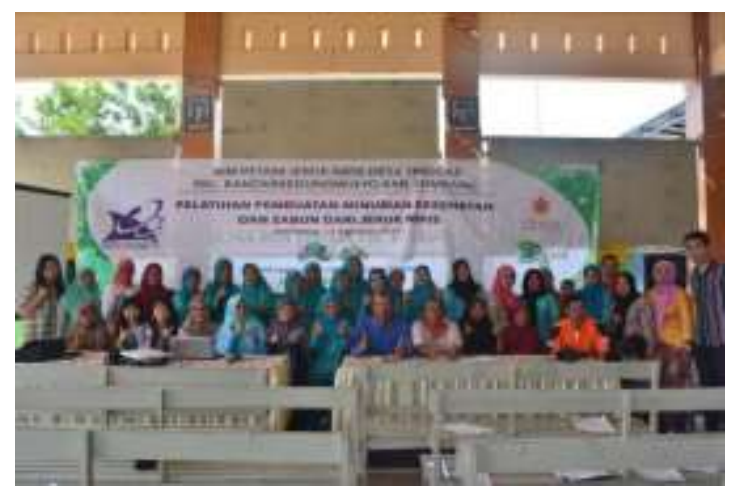

Gambar 2 Peserta pelatihan pembuatan minuman kesehatan dan sabun dari jeruk nipis.
Kegiatan berlangsung dari pukul 09.00 hingga pukul 13.00, diawali dengan sambutan Kepala Desa Tinggar Bapak M. Madram, S.S. Dalam sambutannya kepala desa menyambut baik kedatangan tim FF UBAYA yang ingin membantu masyarakatnya untuk mengembangkan hasil pertanian unggulan desa ini yakni jeruk nipis. Kegiatan pelatihan kemudian berlanjut dengan penyampaian materi pembuatan sabun diikuti materi pembuatan minuman kesehatan. Setelah mengikuti paparan, peserta kemudian mempraktekkan cara pembuatan produk tersebut dengan menggunakan alat dan bahan yang telah disiapkan oleh tim (Gambar 4, 5, dan 6). Peserta terlihat sangat antusias melakukan praktek, menggunakan alat-alat, sampai mencoba produk yang telah dibuat (Gambar 6).

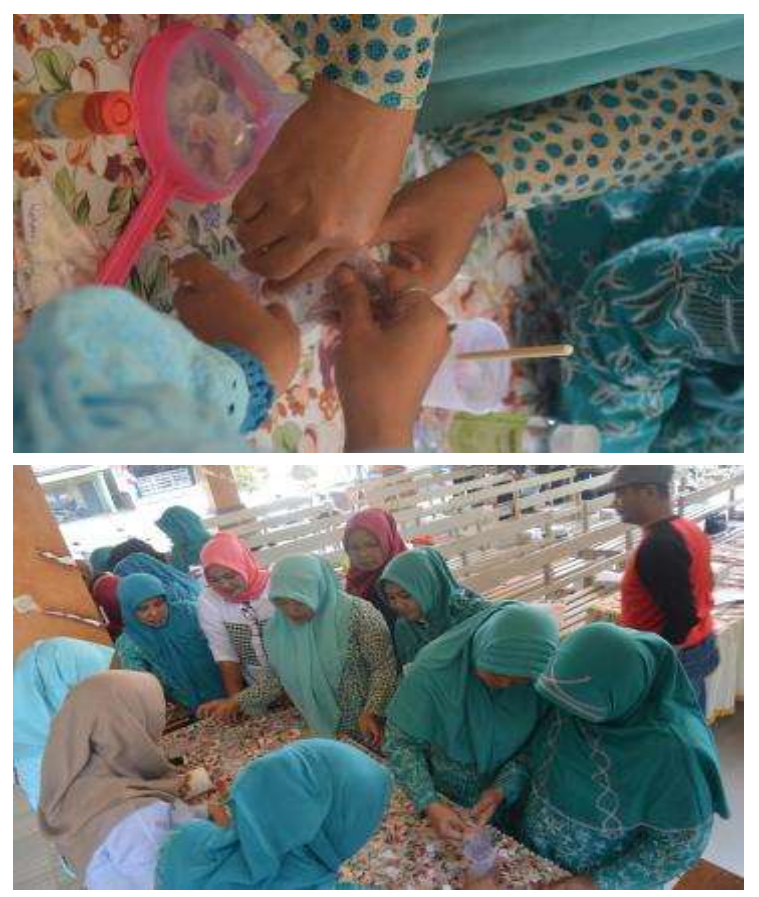

Gambar 3 Proses pembuatan minuman segar dari jeruk nipis. 


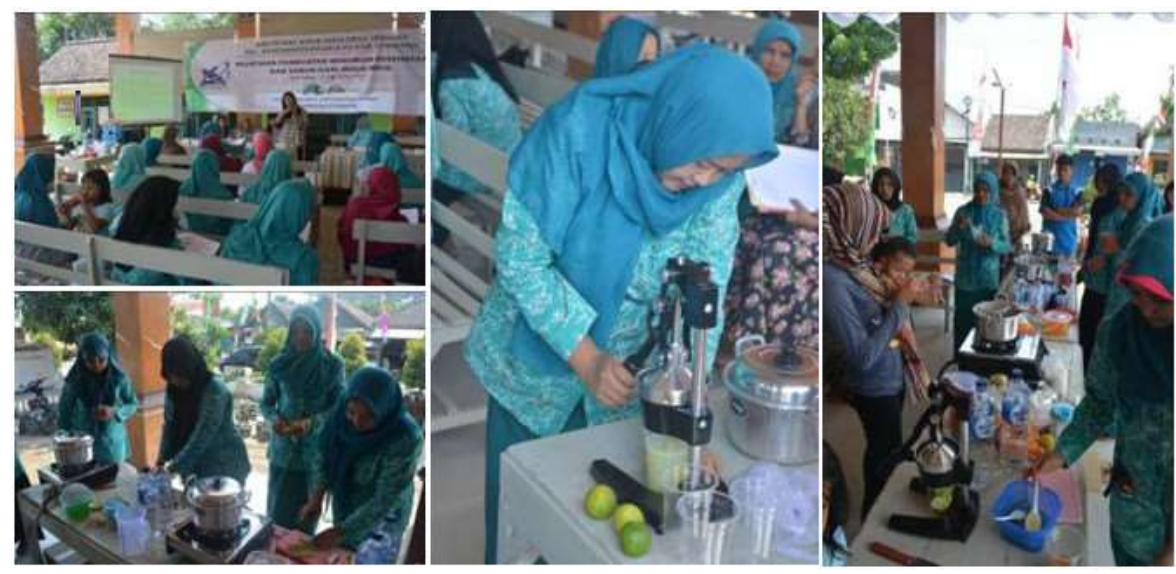

Gambar 4. Proses lanjutan pembuatan minuman segar dari jeruk nipis.
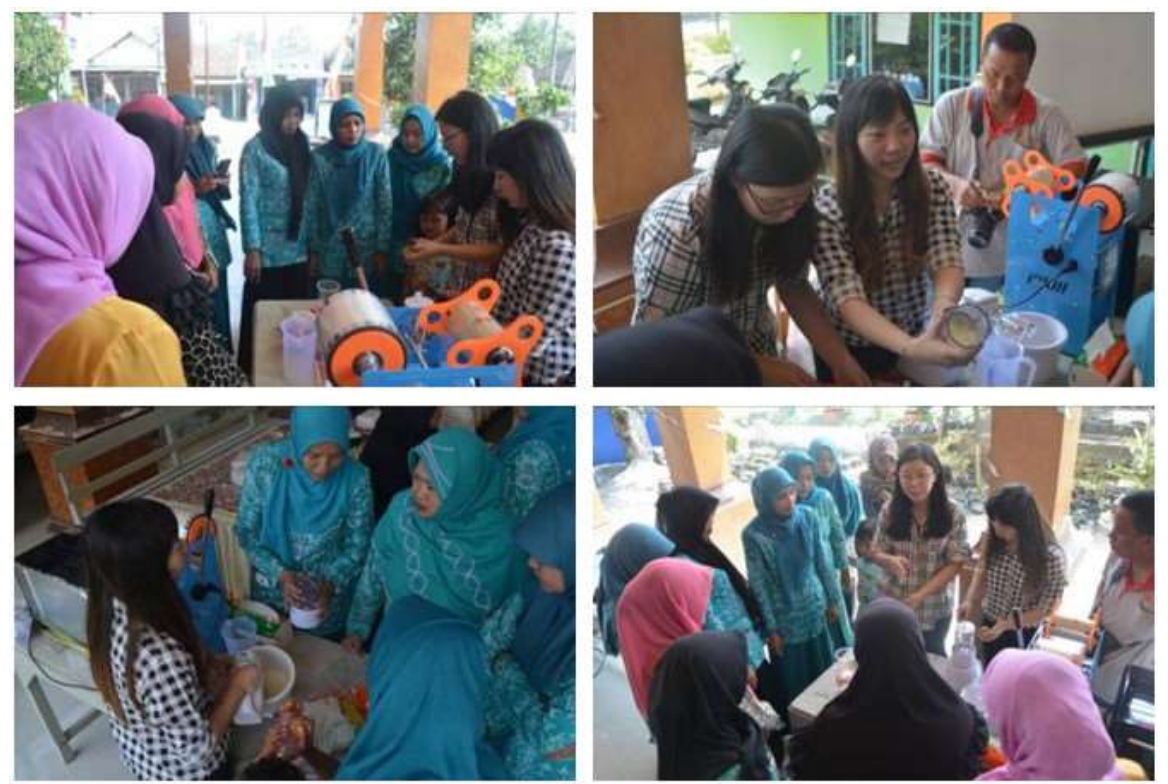

Gambar 5. Proses pembuatan minuman serbuk dari jeruk nipis.
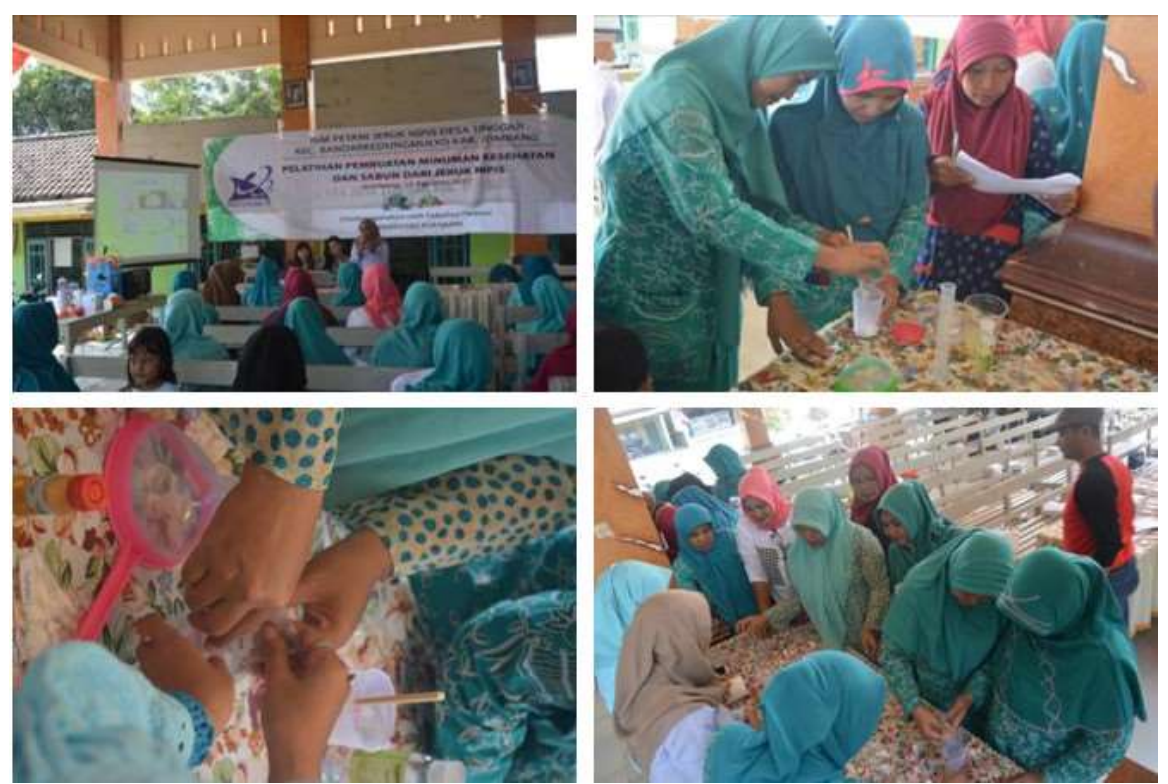

Gambar 6. Proses pembuatan sabun cuci tangan dari jeruk nipis. 

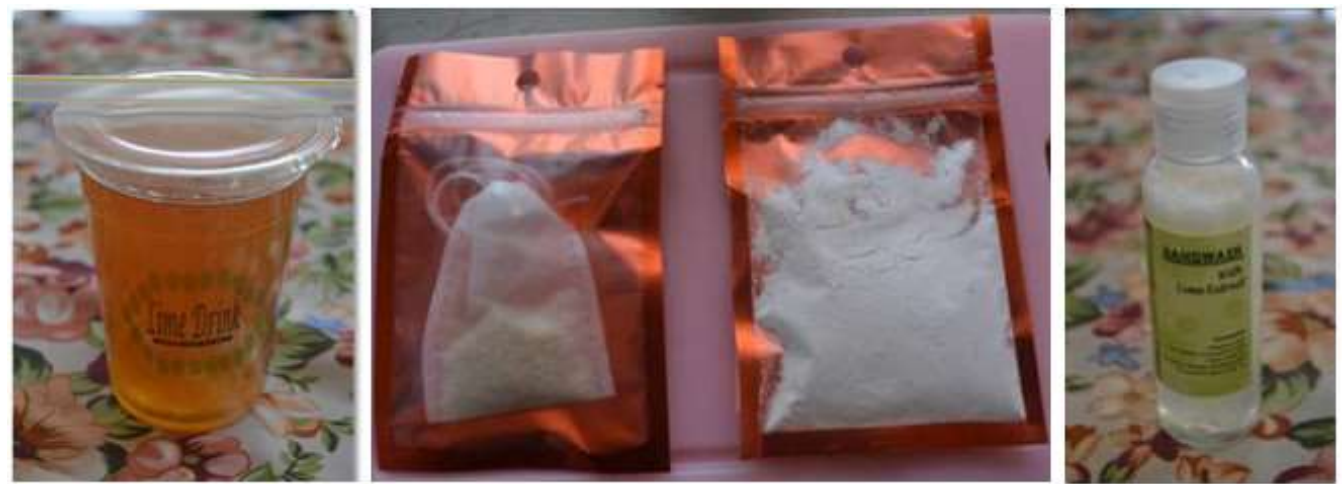

Gambar 7. Produk hasil pelatihan pengolahan jeruk nipis.

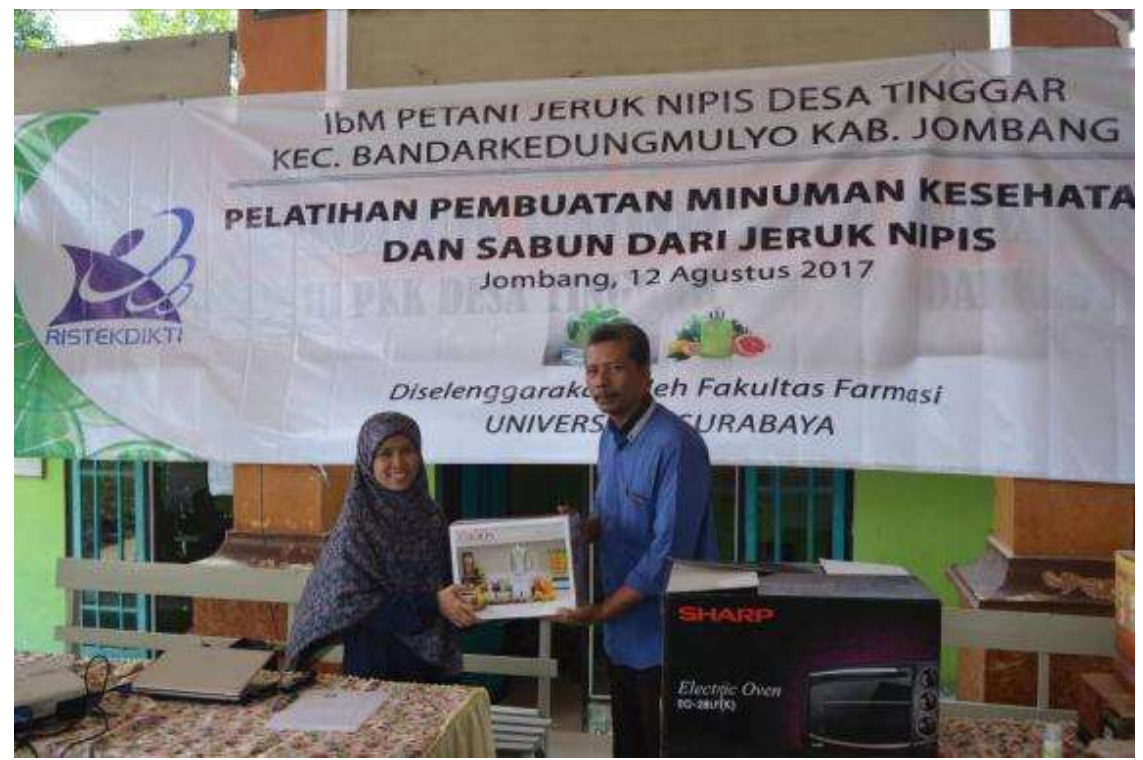

Gambar 8. Penyerahan peralatan pengolahan jeruk nipis.
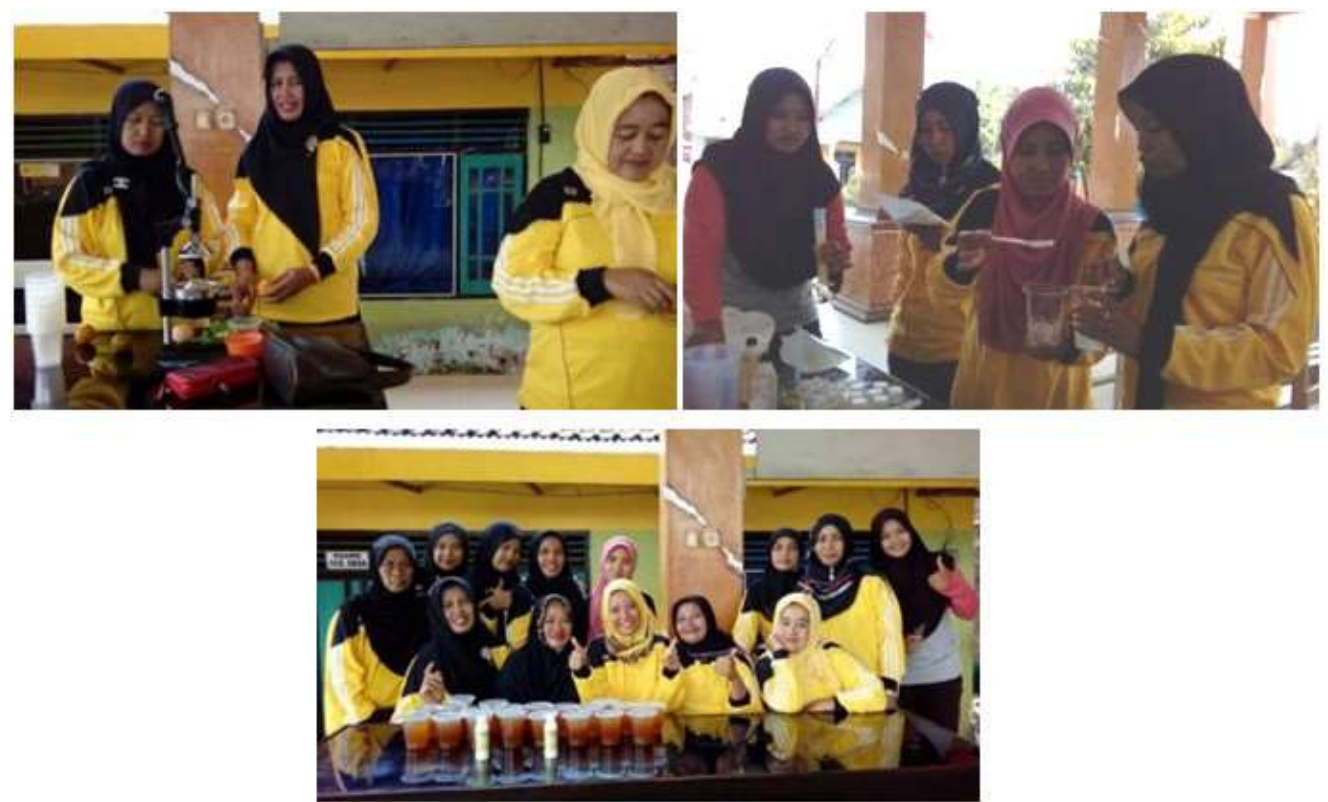

Gambar 9. Pembuatan produk minuman dan sabun dari jeruk nipis oleh kelompok mitra. 


\section{Penyerahan Alat Produksi}

Penyerahan alat dan bahan dilakukan oleh ketua tim kepada kelompok tani jeruk nipis dan ibu-ibu kader PKK yang secara simbolis diwakili oleh Kepala Desa (Gambar 8).

\section{Monitoring dan Pendampingan Pasca Pelatihan Pembuatan Produk Olahan Jeruk Nipis}

Monitoring dan pendampingan kepada mitra dilaksanakan pada hari Sabtu, 9 September 2017. Tantangan yang masih dihadapi oleh mitra dalam pembuatan produk minuman segar adalah masalah daya simpan produk. Solusi yang ditawarkan adalah minuman disimpan dalam lemari es sehingga bisa bertahan 7 hari (hasil percobaan saat studi praformulasi yang dilakukn di laboratorium Fitokimia Universitas Surabaya), atau ditambahkan pengawet minuman yang aman, seperti natrium benzoat 0,03-0,2 \%, yang sesuai jika diberikan pada makanan dengan suasana asam (FAO, 2017). Secara alami perasan air jeruk nipis bisa menjadi pengawet, hal ini karena adanya kandungan citric acid pada buah citrus. Namun kemampuan sebagai pengawet kurang efektif dibandingkan dengan pengawet lainnya (FAO, 2017). Penelitian juga menunjukkan bahwa penambahan air perasan jeruk nipis pada minuman Zobo (minuman tradisional Nigeria yang berasal dari Rosella) dapat memperpanjang waktu kadaluarsa produk tersebut (Onuoha dan
Kaayode, 2014). Setelah dilakukan monitoring, kelompok mitra secara mandiri melakukan pembuatan produk minuman segar dan sabun dari jeruk nipis untuk dipasarkan (Gambar 9).

\section{KESIMPULAN}

Beberapa kesimpulan yang dapat diambil dari kegiatan ini adalah:

1. Kegiatan pengabdian kepada masyarakat yang telah dilakukan dapat meningkatkan pengetahuan dan ketrampilan dalam mengolah jeruk nipis sehingga dapat meningkatkan nilai jualnya;

2. Luaran kegiatan adalah modul cara mengolah jeruk nipis serta produk olahan jeruk nipis berupa minuman fungsional dan sabun cuci tangan.

\section{UCAPAN TERIMA KASIH}

Ucapan terima kasih disampaikan kepada Kemenristek Dikti yang telah mendanai kegiatan ini melalui skim Program Kemitraan Masyarakat (PKM), dengan nomor kontrak 014/SPPPPM/LPPM-02/DRPM/FF/V/2017.

\section{KEPUSTAKAAN}

Aibinu I, Adenipekun T, Adelowotan T, Ogunsanya T, Odugbemi T., 2007. Evaluation of the Antimicrobial Properties of Different Parts of Citrus aurantifolia (lime fruit) as used locally. African Journal of Traditional Complement and Alternative Medicine; 4(2):185-90. 
Apraj, Vinita., NirmalaDevi Thakur, Ashok Bhagwat, Rashmi Mallya, Laxman Sawant dan Nancy Pandita., 2011. Pharmacognostic and Phytochemical Evaluation of Citrus aurantifolia (Christm) Swingle Peel. Pharmacognosy Journal. October 2011 : Vol 3. Issue 26

Apriyani, Diniah, TN. Saifullah S dan Peni Indrayudha, 2013. Formulasi Sediaan Sabun Mandi Cair Minyak Atsiri Jeruk Nipis (Citrus aurantifolia) dengan Cocoamide DEA sebagai Surfaktan. SKRIPSI FAKULTAS FARMASI UGM

Bostham, Maryam., Jamal Moshtaghian, Gholamali Naderi, Seddigheh Asgary dan Hanshem Nayeri., 2011. Antioxidant Effects of Citrus aurantifolia (Christm) Juice and Peel Extract on LDL Oxidation. I Res Med Sci. Jul;16(7):951-5

Elon, Yunus dan Jacqueline Polancos, 2015. Manfaat Jeruk Nipis (Citrus aurantifolia) dan Olahraga untuk Menurunkan Kolesterol Total Klien Dewasa. JURNAL SKOLASTIK KEPERAWATAN Vol. 1, No 12

Ferguson U. Citrus Fruits Processing. Horticultural Science, Florida, 1990, 117-118.

Food and Agriculture of The United Nations (FAO), 2017. Preservatives. www.FAO.org. diakses pada 14 Oktober 2017

Khanifah, Firda. 2015. Efek Pemberian Air Perasan Jeruk Nipis (Citrus aurantifolia (Christm) Swingle) Terhadap Pembentukan, Pertumbuhan dan
Penghancuraan Biofilm Staphylococcus aureus secara in vitro. Skripsi. Fakultaas Kedokteran dan Ilmu Kesehatan Program Studi Farmasi UIN Syarif Hidayatullah Jakarta

Khare CP., 2007. Indian Medicinal Plants: An Illustrated Dictionary. Springer, Berlin, 154.

Loizzo, Monica Rosa., Rosa Tundis, Marco Bonesi, Federica Manichini, Damiano De Luca, Carmela Colica dan Francesco Menichini., 2012. Evaluation of Citrus aurantifolia Peel and Leaves Extracts for their Chemical Composition, Antioxidant and Anti-cholinesterase Activities. Journal o The Science of Food and agriculture Volume 92, issue 15. Pages 2960-2967

Nwachukwu E, Onovo OM, Ezeama CF, 2007. Effect of Lime Juice on the Bacterial Quality of Zobo Drinks Locally Produced in Nigeria. Research Journal of Microbiology.; 2:787-791.

Onuoha, Stanley Chukwudozie dan Kayode Fatokun, 2014. Effect of Citrus aurantifolia Juice on the Shelfi Life of Zobo Drink Produced Locally in Afikpo, Ebonyi State, Ngeria. American Journal Of Bioscience; 2(2): 45-48

Papas, A.M. (1998). Antioxidant Status, Diet, Nutrition and Health. CRC Press. New York.

Syamsulhidayat, S dan J. R Hutape. 1991. Inventaris Tanaman Obat Indonesia. Badan Penelitian dan Pengembangan Kesehatan.Depkes RI. Jakarta . 144 